DOI: $10.1515 /$ ausfm-2018-0005

\title{
On the Role of Diegetic Electronic Screens in Contemporary European Films
}

\author{
Andrea Virginás \\ Sapientia Hungarian University of Transylvania (Cluj-Napoca, Romania) \\ E-mail: andrea.virginas@kv.sapientia.ro
}

\begin{abstract}
Given the present proliferation of profilmic electronic screens in narrative feature films, it is of some interest to examine their role apart from that of denoting objects pertaining to everyday reality. Electronic screens within the European-type filmic diegeses - characterized by adhering to conventions of (hyper)realism, non-hypermediation and charactercentered storytelling - in a digital era are used not only as props, but as frames that re-order and aestheticize levels of reality (Odin 2016), while focusing, in a hypnotic manner, the viewers' attention (Chateau 2016) on traumatic memories related to usually female characters, and consequently to the collectivities they represent in the respective diegetic worlds. These electronic screens force the viewer to constantly shift between the actual cinematic screen conventions and the mental screen (Odin 2016) of smaller formats, training the film viewers for experiences of expanded and fragmented cinema (Gaudreault and Marion 2015). ${ }^{1}$
\end{abstract}

Keywords: cinematic screen, electronic screen, European cinema, diegesis, trauma representation.

While once present chiefly in sci-fi environments or paranoid thrillers, electronic screens - television, video, computer, mobile, surveillance devices - have become built-in elements of film diegetic worlds, generating what Giuliana Bruno names "the ever-present environmental screen-effect within which we now live” (Bruno 2014, 102). The embedding of these electronic screens in fiction film narratives may be considered one of the most pervasive ways our culture tries to deal with - nowadays digital - multi-screen realities, offering us cognitive representational models to use in our everyday lives, simultaneously to creating complex narrative structures that are based on the interplay of filmic reality levels ${ }^{2}$ and narrative diegetic levels.

1 This work was supported by a grant of the Ministry of National Education, CNCS - UEFISCDI Romania, project number PN-III-P4-ID-PCE-2016-0418.

2 Warren Buckland summarizes Étienne Souriau's filmic reality levels as follows: "1. Afilmic reality (the reality that exists independently of filmic reality); 2. Profilmic reality (the reality 
In their co-authored volume The End of Cinema? André Gaudreault and Philippe Marion set up a system based on $20^{\text {th }}$-century media history, taking as a principle the substitution of the cinema silk screen by the electronic cathodic television screen, and then by the electronic portable small computer screen. ${ }^{3}$ They argue that "we might even view the emergence of the small (but highly cathodic) screen as the point of rupture between a 'hegemonic cinema' and this 'cinema in the process of being demoted and shared,' which is often called 'expanded cinema' but which we believe would be more appropriately described as 'fragmented cinema' (Gaudreault and Marion 2015, 11, citing Guillaume Soulez's conference intervention). Thus "hegemonic cinema" would denote the first part of the $20^{\text {th }}$ century, when the cinema theatre silk screen was the sole framed surface which displayed electronically mediated, and also always prerecorded moving images. "Expanded cinema" should denote developments of the second part of the $20^{\text {th }}$ century, when television, and then video-camera screen appeared as electronic surfaces where cinematic worlds and narratives would expand, obviously altering the nature and the significance of framed storytelling based on moving images. Finally, the $21^{\text {st }}$ century brought us into the era of what Gaudreault and Marion name "fragmented cinema," with the same cinematically constructed narrative worlds scattering further on "the electronic portable small computer screen," becoming compatible with such surfaces. My analyses show that cinematic diegetic worlds react elastically to these mutations, the smaller electronic, usually portable screens being entrusted with the weight of essentially truthful images once they, as profilmic objects, appear on "hegemonic cinema screens," in a successful survival strategy of what Gaudreault and Marion call "non-hegemonic-cinema-in-the-digital-era" $(2015,14)$.

With a varied set of examples from contemporary European cinema - Lucian Pintilie's 1993 The Oak (Balanța), Nils Arden Oplev's 2009 The Girl with the Dragon Tattoo (Män som hatar kvinnor), Olivier Assayas's 2014 The Clouds of Sils Maria, Thomas Vinterberg's 2016 Commune (Kollektivet), Andrei Zvyagintsev's 2017 Loveless (Nelyubov) or Ruben Östlund's 2017 The Square -, my examination

photographed by the camera); 3. Filmographic reality (the film as physical object, structured by techniques such as editing); 4 . Screenic (or filmophanic) reality (the film as projected on a screen); 5 . Diegetic reality (the fictional story world created by the film); 6 . Spectatorial reality (the spectator's perception and comprehension of a film); 7. Creational reality (the filmmaker's intentions)" (Buckland 2003, 47).

3 "One of the principal effects of the digital shift has been the big screen's loss of hegemony. [...] In fact projection onto a movie screen has become just one way among others to consume images. The screen may have a greater aura, but it is now just one means of consumption among others." (Gaudreault and Marion 2015, 9.) 
focuses on the role of various diegetic electronic screens, mapping intermedial tensions between video/computer/television screens and the filmic/cinematic screen. As a hypothesis that organizes the analysis of the mentioned corpus I propose that electronic screens within the European-type - (hyper)realistic (Casetti 1998, 56), ${ }^{4}$ non-hypermediated, character-centered - filmic diegeses in a digital era are of a specific nature. They are highlighted surfaces which might represent traumatic memories that are not only haunting and unpleasant, but also formative of chief female characters, and of the social and/or ethnic collectivities they represent, often allegorically, in the respective diegetic worlds.

Two frameworks of understanding need to be mentioned as these influence in a fundamental mode my hypothesis and the subsequent results. First, my long-term engagement with analysing the role and appearance of various screen surfaces in film diegesis, especially such cases when, besides being props, these multiple, non-cinematic screens also carry narratively significant information, which has the power to influence the first-level narrative thread of the films as such (see Virginás 2014a and 2017). This endeavour luckily blends with the post2015 resurgence of interest in screens and their theories, the vanishing point of which might be this observation of Roger Odin: "this trivialization of the framescreen [e.g. due to the proliferation of mobile small screens] should not hide the opposite trend, even if it is still marginal: its disappearance with the emergence of virtual reality" (Odin 2016, 185).

Secondly, cultural trauma theory needs to be invoked, and the analyses I pursued regarding the representation of such gender-specific female traumas as rape within the conventions of cinematic diegesis (see Virginás 2014b; 2016 and 2018). Ann Rigney identifies traumas as "events which, although they are remembered vividly in the hearts and minds of their victims, nevertheless defy sayability in the usual modes of public recollection," and she adds that "creativity and imagination are needed if certain memories are to be made shareable at all" (Rigney 2016, 72). Janet Walker's highly influential concept of "trauma cinema," ${ }^{5}$ Susannah

4 And here I refer to the definition of hyperrealism in cinema as theorized by Francesco Casetti: "hyperrealism is based not so much on careful and slightly abstract scenography as on the operation's ability to find the elements within itself for orienting the audio-visual discourse. Any impression of extravagance and overabundance results less from the nature of the materials staged for the camera than from the task of the technical apparatus to present itself as the origin and finality of its own functioning, much in the manner of a 'bachelor machine'” (Casetti 1998, 56).

5 "The stylistic and narrative modality of trauma cinema is nonrealist. Like traumatic memories that feature vivid bodily and visual sensation over verbal narrative and context, these films are characterized by non-linearity, fragmentation, nonsynchronous sound, repetition, rapid editing and strange angles. And they approach the past through an unusual admixture of emotional affect, metonymic symbolism and cinematic flashbacks.” (Walker 2001, 214.) 
Radstone’s "cinema/memory," ${ }^{\circ}$ or Astrid Erll and Stephanie Wodianka's term, "Erinnerungsfilm/memory film" " definitely fit Rigney's postulate of creativity and imagination when representing traumatic memories. I suggest that the integration of multiple electronic screens in the filmic diegesis, where the traumatic material embodied as female and situated in social and historical terms - is banished, may be positioned as a further creative method. This method is also highly characteristic of our era in its contrasting, but also hybridizing the electronic and the cinematic screens, the fundamental difference of which was assessed by Vivian Sobchack in a 1990 essay exactly in their non/capacity of generating a diegetic reality through point of view: "ungrounded and uninvested as it is, electronic presence has neither a point of view nor a visual situation, such as we experience, respectively, with the photograph and the cinema" (Sobchack 2000, 80-81).

In a relatively early example, in Lucian Pintilie's The Oak (1992) we have an inserted profilmic screen, well differentiated from the cinematic narrative screen, already in the introductory title sequence. The female protagonist, Nela (Maia Morgenstern), lies in an unmade bed with his terminally ill father, and a celluloid Super 8 home movie projector is in function, placed between them on the bed, and projecting its content on the opposite wall in the cramped little room. The home video presents a long gone St. Nicholas/Christmas party, with high ranking communist army and party officials celebrating in an elite communist mansion, persons we possibly identify as Nela's and her father's former entourage, while the little girl taking center stage in the events seems to be herself, several decades ago. Pintilie's diegetic screen is not an electronic one, but a projected smaller frame that Wanda Strauven considers as a "vertical viewing dispositif" (Strauven 2016, 144), which concentrates all the qualities of the framed view as described by Roger Odin: "a first observation is that the fact of framing helps us to see better and make the world be seen. [...] All the theorists of the frame emphasize its power of concentration (preventing the gaze from wandering), insulation and ostension (it has a deictic value)" (Odin 2016, 183).

At the same time, this frame projected by the home video in The Oak contains essential data that will prove to be fundamental by the end of the screen time,

6 "In place of formulations that give primacy to cinema or to memory, what emerges is a liminal conception of cinema/memory, where the boundaries between memory and cinema are dissolved in favour of a view of their mutuality and inseparability." (Radstone paraphrased by Collenberg-Gonzalez 2016, 249.)

7 As summarized by Collenberg-Gonzalez $(2016,248)$, these are: "Films that thematize memory and are seeped within a memory culture as demonstrated in the types of documentaries, making of, and marketing paraphernalia that encourage remembering." 
although at this point in the narrative there is no chance for the first-time viewer to assess the relevance of the projected video material. This relevance might only be intuited by submitting to what Dominique Chateau terms "the hypnosis of the screen," via perceptually guided, physical processes: "the screen is hypnotic. Light somehow replaces the stare of the hypnotist. Two characteristics of the screen remind us of fascination as psychoanalysis envisaged it (including Freud and Lacan): first, it depends upon a restriction of the object to one of its aspects and, correlatively, requires a strong focus of the gaze; second, it captures not only the gaze, but the mind in a way that reminds us of hypnosis" (Chateau 2016, 197). The force of the hypnotic screen will be re-confirmed to the viewer retroactively, when the meaning and conditions of the highly memorable final freeze frame of the film, with adult Nela looking at the spectator, will acquire a full-rounded meaning only if one returns to the introductory home movie sequence projected on the wall and re-assesses its relevance for the narrative just viewed. Nela is the main focalizer character in the narrative, it is her multiple personal traumas and the collective traumas of Romanians under communist dictatorship that are highlighted in this short home video, with Giuliana Bruno's ontological definition of (the) screen fully operative throughout the sequence: "an actual projective surface onto which an experience of close relations between subject and object is inscribed, in a way that overcomes divisions between outside and inside, inward and outward" (Bruno 2014, 86).

A valuable contribution to understanding the survival strategies of what Gaudreault and Marion name "non-hegemonic cinema-in-the-digital-era" (2015, 14 ) is Roger Odin's conception of various screen types in his 2016 study. Here he differentiates between physical, mental or internalized, and dream screens based on a materialist-phenomenological grounding similar to what was palpable in Sobchack's delimitation of the photographic, the cinematic and the electronic screen eras (2000). Odin states that "the notion of a mental screen corresponds to physical screens (cinema, television) that have become mental spaces. Dream screens are mental screens waiting for physical manifestation; one must note that this type of screen is the source of certain inventions: cinema and television have been dream screens before being invented" (Odin 2016, 185). Odin pays special attention to the "mental cinema screen" that constitutes the kernel of his argumentation, and which is operative in our contemporary practices of watching (feature) films on various non-cinematic screens. He suggests that "cinema has become a mental screen, a screen that functions as a constraint when you see a movie in a physical communication space other than the cinema 
space" (Odin 2016, 177). Examples like Nela and her father's home video sequence from Pintilie's The Oak force the viewer to constantly shift between the actual cinematic screen and the mental screen not of cinema, as Roger Odin formulates, but of the mental construction of smaller format electronic screens. Staging narratively relevant information on home video projections, on television screens, or on mobile smartphone screens seems to prepare and/or train the film viewers for the inevitable transformations that need to be pursued when leaving behind Gaudreault and Marion's hegemonic cinema for the sake of its expanded, and later fragmented variant in the $21^{\text {st }}$ century.

This mechanism is fully at work in the two short sequences preceding the end of Andrei Zvyagintsev's 2017 Loveless, when the search for missing 11year old Aljosa is over, and the two parents are settled with their new families/ partners. The father (Aleksey Rozin) is seen in a narrow room in a block of flats, with a framed tapestry of forest animals behind him, and the flat TV screen's hypnotizing beams broadcasting about the war in Ukraine in front of him. The son is visibly unable to capture the affection of his father. The mother (Maryana Spivak) is also watching TV in the elegant upper middle-class interior of her partner's home, simultaneously to being occupied with her smartphone screen. A news programme informing about casualties in the Russian-Ukrainian war is transmitted and shown to the viewers on a diegetic television screen, containing the testimony of distressed locals, a view faced by a mother who has recently had her son gone missing. With the television broadcast's sonic aura fully effective throughout the sequence - as was in the previous scene with the father's new family - the mother putting on a sportswear with a "Russia" inscription on it becomes a deeply symbolic gesture. As she goes outside to run on the treadmill further non-cinematic mental screen operators are inserted in the image, besides the already present television and smartphone screens. [Fig. 1.] The mother is framed by large French windows, clearly separating the grey and spacious interior from the trees outside on which snow starts to fall, furthermore she also manipulates the treadmill's electronic screen to regulate the speed of the band. In the next shot a fix camera films the running woman, and when the camera slowly starts to narrow its focus, trapping the running female figure in an even tighter frame of cinematic screen, the mother stops her determined workout, and facing the camera, clearly breaks the fourth wall. [Fig. 2.] Female and motherly trauma, over-politicized and nationally allegorized through the television signals of the Ukrainian war and her red sweater with the "Russia" inscription on it, is conveyed through a fix image of a cinematic nature. This cinematic image 
bordering on stillness is, however, fundamentally dependent on the encaging operations of the several non-cinematic frames (some of them also screens) active in such a short scene: the smartphone screen, the television screen, the French window, the treadmill's laptop screen, and finally the filming camera's dissecting framing activity, made present through the slow focusing advancement.

In Nils Arden Oplev's 2009 adaptation, The Girl with the Dragon Tattoo (Män som hatar kvinnor), detecting journalist Michael Blomkvist (Michael Nyqvist) analyses the report photo series taken on the day of the murder of sexually abused victim Harriet Vanger (Julia Sporre). After having digitized them, he dissects their surface by a repetitive imposition of tighter and tighter frames on the originally high-angle panorama shot taken from a street-side balcony. The last moments of the photographs extending over the whole screen surface of the cinematic diegesis are wrapped by the voice-over of old Henrik Vanger, who informs us that "this is the first trace in the case [investigated] in 39 years," the sequence ending with the two men looking at a computer screen in a sumptuous office-room. It is in their conversation that the seeds of traumatic interpretation are planted: "her murderer" must have caught Harriet's look apparently directly staring at us. [Fig. 3.] The gesture of Harriet's breaking the fourth wall, in a moment reminiscent of the mother's look in Loveless, evokes the category of Francesco Casetti's "interpellation" (1998). ${ }^{8}$ It is indicative of the trauma buried inside the long-gone female character, who exists as a memory, as a ghost in(side) the firstlevel narration/diegetic world, while also an explicit index pointing towards the group of morally corrupt industrial magnates, emphasizing their role as buriers of Swedish social democracy.

Roger Odin's already cited media anthropological observation referring to "cinema ha[ving] become a mental screen, a screen that functions as a constraint" (Odin 2016, 177) can be said to be figuratively staged in these European filmic diegetic narratives in such moments when the originally non-cinematic, electronic, (intra)diegetic images are morphing into close-ups with an ambiguous diegetic status that tend to engulf the whole cinematic screen for several seconds of the narrative screen time. A further example might be cited from Ruben Östlund's 2017 The Square, when the dominant art museum curator Christian's (Claes Bang) descent into a series of traumatizing events has already started, and he sees for the first time the marketing video that went viral for the artwork The

8 "A direct address to a virtual spectator, a gaze and voice from the screen aimed at this individual as if to invite him to participate in the action. [...] the recognition of someone who, in turn, is expected to recognize himself as the immediate interlocutor." (Casetti 1998, 16.) 
Square. This artwork, further qualified "as a sanctuary, a zone of trust and care" is actually a frame that creates a different scale and order of reality in the confines of museum space, or in Odin's words: "framing is not just simple observation: the screen is a mental operator, a filter that produces distance and changes the perception of reality as it introduces points of reference (the edges of the frame) that lead us to build relationships that do not exist in reality" (Odin 2016, 83).

Christian starts to view on his infamous smartphone the video that through its politically incorrect depiction of an exploding blonde child beggar has generated a huge number of views on YouTube. [Fig. 4.] The promotional viral video displays the most traumatic, but also most traumatizing visual material, linked to child/female trauma, of the otherwise highly daring film. Hitherto framed by a small electronic screen, the exploding blonde child beggar will cover the whole cinematic screen, and the fade in, fade out, slide-like construction of the video clip emphasizes its nature different from the filmic image and screen, an effect intensified by the clip's similarities to terrorist activist videos. The violently politically incorrect video taps into the hidden fears and wishes of many civilized and cultured Swedes, with the exploding beggar girl framed by a small screen that allegorizes whole ethnic/social collectivities as was the case with Nela in The Oak, or Harriet in The Girl with the Dragon Tattoo, and the mother in Loveless. In The Square also the electronic, non-cinematic screens, apparently scattered through the diegetic world as non-significant profilmic props with the function of emanating a-filmic-ness, creating what Roland Barthes names "l'effet du réel" $(1968,88)$, not only reflect, deflect and interpret the first-level narrative, but are also reserved to contain the truly traumatic/traumatizing ultimate truths that cannot be handled through the given system of representation of the linear, realist-type narrative diegesis.

The recurrent interplay of non-cinematic, projected or electronic screens, and cinematic screens in recent European films is definitely based on the exploitation of focused attention, borderlines, and cognitive edges introduced in a semiotically charged filmic diegetic world, and it might be attributed to the responsibility, and even burden, of representing traumatic experiences of collectivities through immobilizing and de-framing female characters from the diegetic events. The connected collectivities might be ethnically, economically, or socially coded: (post)communist Romanians, (post)welfare Swedes, (post)democratic Russians, or (post)liberal Danes and (post)analogue French populate these not-so-fictive worlds.

In Thomas Vinterberg's The Commune we are presented the life of a Copenhagen commune during the Cambodian war (1975-1977). Anna (Tryne Dyrholm) and Erik (Ulrich Thomsen) own the house where the commune is living, Anna being 
a famous news-presenter in Danish public television, while Erik a university teacher in architecture, and they have together a teenage daughter. Anna's descent into the circles of her and the commune's private, but also personal hells start to intensify when Erik, her faithful, loyal and kind husband falls in love with his young and beautiful student, Emma. Given the timeframe of the diegetic world, the main non-cinematic, electronic screen that hovers over this diegetic world is the analogue, black-and-white television set's flat and small screen, on which Anna's uptight torso and officially kind face appears several times over the narrative. [Fig. 5.] Within this sequence the camera moves horizontally, leaving Anna and Erik's daughter and her boyfriend making love on the bed, only to let enter into the frame the television set and de-coloured, distant, mediated Anna, obviously unaware of her daughter's being initiated into sexual life. As the film is coloured and the shot is staged so as to create the feeling of depth in the room, Anna's being encaged by the television set's old-fashioned, low-resolution screen surface starts to develop very early, together with the intradiegetic, yet non-cinematic screen's capacity of commenting and reflecting on the diegetic happenings being made use of in a methodical manner, even before the sequence that demonstrates the method of morphing non-cinematic, electronic diegetic screens into metadiegetic close-ups covering the whole surface of the cinematic screen.

Here we are after Erik's young mistress moved in with the commune, to the generous offer of Anna herself, and the two (rival) women have apparently shared moments of harmony too, when they went shopping together. However, Anna's well-composed facade begins to crack, we see her neurotically tense face during the editorial meeting too, and she cannot bear being made-up by an equally beautiful young woman, being in need of her daily alcohol portion even before entering the television news transmission room. The presence of the various, non-cinematic screens that will morph into metadiegetic shots constituting traumatic screens is also diegetically motivated, as it was in all the previous examples. The cameras' optics circle around the lonely female figure who barely manages to hold herself together and the filmic image chooses to linger on Anna's tense hands, the way she closes her eyes so as to shield her from the world. Her wrinkled and madeup eyes full of sadness and resignation are shown in a strangely framed shot that cuts her face in two: Anna's profilmic close-up fills the cinematic screen even before her television-screen mediated image appears to us. As she is supposed to enter into live transmission, the countdown of the programme coordinator begins, but tears start to flow from Anna's eyes. Her nearly frontal extreme closeup emerges as highly artificial when compared to the previous, more relaxed 
way of framing: interestingly, instead of choosing to show it as seen through a television screen, Vinterberg chooses to show only its supposed effect, as the technical personnel far away starts to wave their hands, having noticed on their electronic monitors that the news presenter is crying, instead of professionally reading the news headlines.

The filmic image keeps on moving between Anna's cinematic close-up, highlighting Tryne Dyrholm's inspired performance, and showing the effect of this performance on the technical personnel of the TV studio. Anna is taken away in a slowed-down sequence, with the pace of the music matching the tragic denouement. The sequence ends with Anna and her two colleagues disappearing in the darkness that envelops the television cameras, and with the diegetic closeup of the black-and-white television screen, which presents an error signal so well known from analogue television era. Thus, though not actually introducing the tragic female face on the television screen - another non-cinematic, smaller electronic screen enclosed in this diegetic world -, Vinterberg succeeds in generating Odin's mental screen, but this time formatted for the television screen. In Vinterberg's The Commune this mental screen materializes as a (meta)diegetic close-up apparently about the failure of Danish television, while also representing the breakdown of Anna, her trauma of being abandoned and left on her own.

My last example is Olivier Assayas's 2014 The Clouds of Sils Maria, a film where the French director juxtaposes the generation of digital immigrants to that of digital natives by showing these, on the one hand, as women in masked hierarchical relationships to each other, and on the other hand, by creating a diegetic world about contemporary theatre and filmmaking as deeply embedded within the online internet sphere. Maria Enders (Juliette Binoche) is a worldfamous actress with a long career, weary of the digital ("I'm sick of acting hanging from wires in front of green screen" - she categorizes her experiences in action blockbusters) and who embraces the analogue. Maria is contrasted with both Valentine (Kristen Stewart) - her young assistant, whose two smartphones and tablet are fully integrated into her flesh-and-bone existence - and Jo-Ann Ellis (Chloë Grace Moretz), a Hollywood fantasy blockbuster superstar, famous for her private scandals gone viral.

The final part of Clouds in Sils Maria presents the theatrical performance of the play entitled Maloja Snake: the story of a powerful firm executive (Helena as played by Maria Enders) and her painful lesbian love story with her ruthless young assistant (Sigrid as played by Jo-Ann Ellis). Sigrid enters the cubes signifying the company offices, takes files from the desks of the office workers, and at the 
end of the theatrical scene (but also of that of the filmic sequence) she exits the geometrical, sterile office space towards the audience, stopping at the extreme edge of the stage. The camera focuses on Jo-Ann-as-Sigrid's angry, disillusioned, tired and sad face: this female face is filmed in real-time and projected on the huge canvas of the stage in magnified proportions, with a bluish lighting effect overimposed on it. The view created is that of a beautiful female head squeezed through the grid of pixels and geometrical lines that define such a body in a digital environment of $1 \mathrm{~s}$ and $0 \mathrm{~s}$. The analogue narrative filmic image of an actress performing a role in the sketchy environment of a theatre play is transmediated into the digital filmic image of the same theatre actress in the front of our very eyes, creating a hybrid representation that is neither analogue filmic image, nor filmed theatre scene, or digital filmic image, but all of these at the same time.

Such (intra)diegetic shots transforming into (meta)diegetic, long-duration, fix shots, which often are close-ups, exemplify what Odin calls "inclusion," e.g. those moments when "the mental cinema screen encompasses and somehow erases the physical space” (Odin 2016, 179). These long-duration shots ambiguous as for their diegetic status - no focalizer character's optical POV matches them - turn into moments of true spectacle offered to the film viewers in a digital era, staging the process of immobilizing animate images, of which Gaudreault and Marion write that "within the flow of digital visual media and through the widespread animation of these media, the 'moveable' image has become almost the norm and the still image the exception" $(2015,77)$. And definitely the urge towards an aesthetic attitude that framing entails is also present in such moments: "the desire to see something 'framed' reflects a will to transform the world into an aesthetic. [...] One can see this movement as a way to extract or at least to protect oneself from the world and its hazards. The frame effect can then turn into a screen effect: framing to make something seen, but also screening oneself from the world" (Odin 2016, 183).

My main question in this essay has been: when we have profilmic electronic screens in a narrative, what is their role apart from denoting everyday reality objects? I suggested that such screens are used not only as props, but as frames that re-order and aestheticize levels of reality, while focusing, in a hypnotic manner, the viewers' attention. The examinations show that these electronic screens also need to contain such traumatic images that constitute the kernel of especially the female main characters, and in this respect they seem to oppose the concept of screens as "mere mediation surfaces." It is of the latter that Marco Rubio writes, based on Richard Barbeau and Raphäel Lellouche's screen theory, 
that "Lellouche's 'l'écran amnesique' somewhat underlines the 'forgetting' of the message by the screens: the screens are becoming a mere format for completely interchangeable messages, mere mediation surfaces, which are not determined by the nature or characteristics of their messages" (Marco Rubio 2016, 221). Finally, these electronic screens force the viewer to constantly shift between the actual cinematic screen conventions and the mental screen not of Odin's cinema, but that of smaller format electronic screens, training the film viewers for experiences of expanded and fragmented cinema.

Thomas Elsaesser proposes a cinema that "does not project itself as a window on the world nor requires fixed boundaries of space like a frame," but "it functions as an ambient form of spectacle and event, where no clear spatial divisions between inside and outside pertain” (Elsaesser 2016, 133). On her turn, Giuliana Bruno observes that " $[w]$ e no longer face or confront a screen only frontally but rather are immersed in an environment of screens" (Bruno 2014, 102), which she also names, based on Pippilotti Rist's 2010 installation Layers Mama Layers, "a fluid, haptic world of surrounding screens," "where one becomes an integral part of a pervasive screen environment in which it is no longer preferable or even possible to be positioned in front of the work" (Bruno 2016, 102). The analysed filmic narrative which embeds multiple electronic screens within the diegesis designed for classical cinematic screen, dispersing relevant narrative information on these screen surfaces, to the degree that it might even generate "multiple diegetic worlds" (Elsaesser 2016, 69) may be considered an intermediary form between fixed screen/fixed spectator photographic cinema and Elsaesser's "ambient form" post-photographic cinema or Bruno's "surround screen environments."

These examples are also instances of technological interactivity within the diegetic filmic worlds for the fictive characters involved. Through their role of questioning, expanding, erasing or simply dispersing the narratively valid information on various electronic surfaces they also force what Gaudreault and Marion name "passive viewer" watching "linear cinema" $(2015,10)$ into a highly active one, who must energize their mental screen for electronic small portable screens within a filmic diegetic world, while simultaneously constructing the narrative world(s) as having multiple, intersecting levels. Interestingly, this trope of/for technological interactivity characteristic of expanded (remote controls) and fragmented (touch-screens) cinema leaves room for hardliner definitions of cinema in the digital $21^{\text {st }}$ century, represented by such doyens of moving image theory as Raymond Bellour or Jacques Aumont, with the latter's axiom - "any presentation of a film which lets me interrupt or modify the experience is not cinema"- (quoted 
by Gaudreault and Marion 2015, 25) remaining valid too. Or as Gaudreault and Marion prophetically formulate: "no matter what happens to it, there always remains something of cinema in the supposedly degraded images of every verysmall-screen device" $(2015,60)$. Such a temporally limited, geographically and culturally defined corpus might also offer us "the archaeology of the screen and frame" (Elsaesser 2016, 112) in a region that has more abruptly collided with convergence culture, being more weakly equipped in dealing with multiscreen realities, yet obviously receptive to global trends in media and gallery art.

\section{References}

Barbeau, Richard. De la contemplation á l'immersion: Une "théorie de l'écran" proposée par Raphäel Lellouche [From Contemplation to Immersion: A “Theory of the Screen” Proposed by Raphäel Lellouche]. Archée. http:// www.archee.qc.ca/ar.php?page=article\&no=5. Last accessed 18. 05. 2018.

Bruno, Giuliana. 2014. Surface: Matters of Aesthetics, Materiality, and Media. Chicago and London: University of Chicago Press.

Buckland, Warren. 2003 [2000]. The Cognitive Semiotics of Films. Cambridge: Cambridge University Press.

Casetti, Francesco. 1998 [1996]. Inside the Gaze: The Fiction Film and Its Spectator. Bloomington and Indianapolis: Indiana University Press.

Chateau, Dominique. 2016. Between Fascination and Denial: The Power of the Screen. In Screens. From Materiality to Spectatorship - A Historical and Theoretical Reassessment, eds. Dominique Chateau and José Moure, 186-199. Amsterdam: Amsterdam University Press.

Gonzalez-Collenberg, Carrie. 2016. Cinema and Memory Studies: Now, Then, and Tomorrow. In Routledge International Handbook of Memory Studies, eds. Anna Lisa Tota and Trever Hagen, 247-258. London, New York: Routledge.

Elsaesser, Thomas. 2016. Film History as Media Archaeology: Tracking Digital Cinema. Amsterdam: Amsterdam University Press.

Gaudreault, André and Philippe Marion. 2015. The End of Cinema? A Medium in Crisis in the Digital Age. New York: Columbia University Press.

Marco, Salvador Rubio. 2016. Dos Passos's USA Trilogy: Current Answers for the Eyeminded Public. In Screens. From Materiality to Spectatorship - A Historical and Theoretical Reassessment, eds. Dominique Chateau and José Moure, 203-222. Amsterdam: Amsterdam University Press. 
Odin, Roger. 2016. The Concept of the Mental Screen: The Internalized Screen, the Dream Screen, and the Constructed Screen. In Screens. From Materiality to Spectatorship - A Historical and Theoretical Reassessment, eds. Dominique Chateau and José Moure, 176-185. Amsterdam: Amsterdam University Press.

Rigney, Ann. 2016. Cultural Memory Studies: Mediation, Narrative, and the Aesthetic. In Routledge International Handbook of Memory Studies, eds. Anna Lisa Tota and Trever Hagen, 65-76. London, New York: Routledge.

Sobchack, Vivian. 2000 [1990]. The Scene of the Screen: Envisioning Cinematic and Electronic "Presence." In Film and Theory: An Anthology, eds. Robert Stam and Toby Miller, 66-84. Malden, MA: Blackwell Publishers.

Strauven, Wanda. 2016. The Screenic Image: Between Verticality and Horizontality, Viewing and Touching, Displaying and Playing. In Screens. From Materiality to Spectatorship - A Historical and Theoretical Reassessment, eds. Dominique Chateau and José Moure, 143-156. Amsterdam: Amsterdam University Press.

Virginás, Andrea. 2014 a. Screens "as Representation" and Screens "as Simulation" in Mainstream Cinema Detection: between Blade Runner (1982) and Splice (2009). The Nordic Journal of Aesthetics 47: 76-93.

Virginás, Andrea. 2014b. Female Trauma in the Films of Szabolcs Hajdu, David Lynch, Cristian Mungiu and Peter Strickland. Studies in Eastern European Cinema vol. 5, no. 2: 155-168.

Virginás, Andrea. 2016. Fragile Diegetic Spaces and Mobile Women: Coping with Trauma in Hungarian and Romanian Films. In Cultural Studies Approaches in the Study of Eastern European Cinema: Spaces, Bodies, Memories, ed. Andrea Virginás, 66-84. Newcastle upon Tyne: Cambridge Scholars Publishing.

Virginás, Andrea. 2017. Gendered Transmediation of the Digital from S1m0ne to Ex Machina: "Visual Pleasure" Reloaded? European Journal of English Studies vol. 21, no. 3: 288-303.

Walker, Janet. 2001. Trauma Cinema: False Memories and True Experience. Screen vol. 42, no. 2 (summer): 211-216. 


\section{List of Figures}

Figures 1-2. Frames and screens encaging the mother. The mother looking at the camera in Loveless (2017).
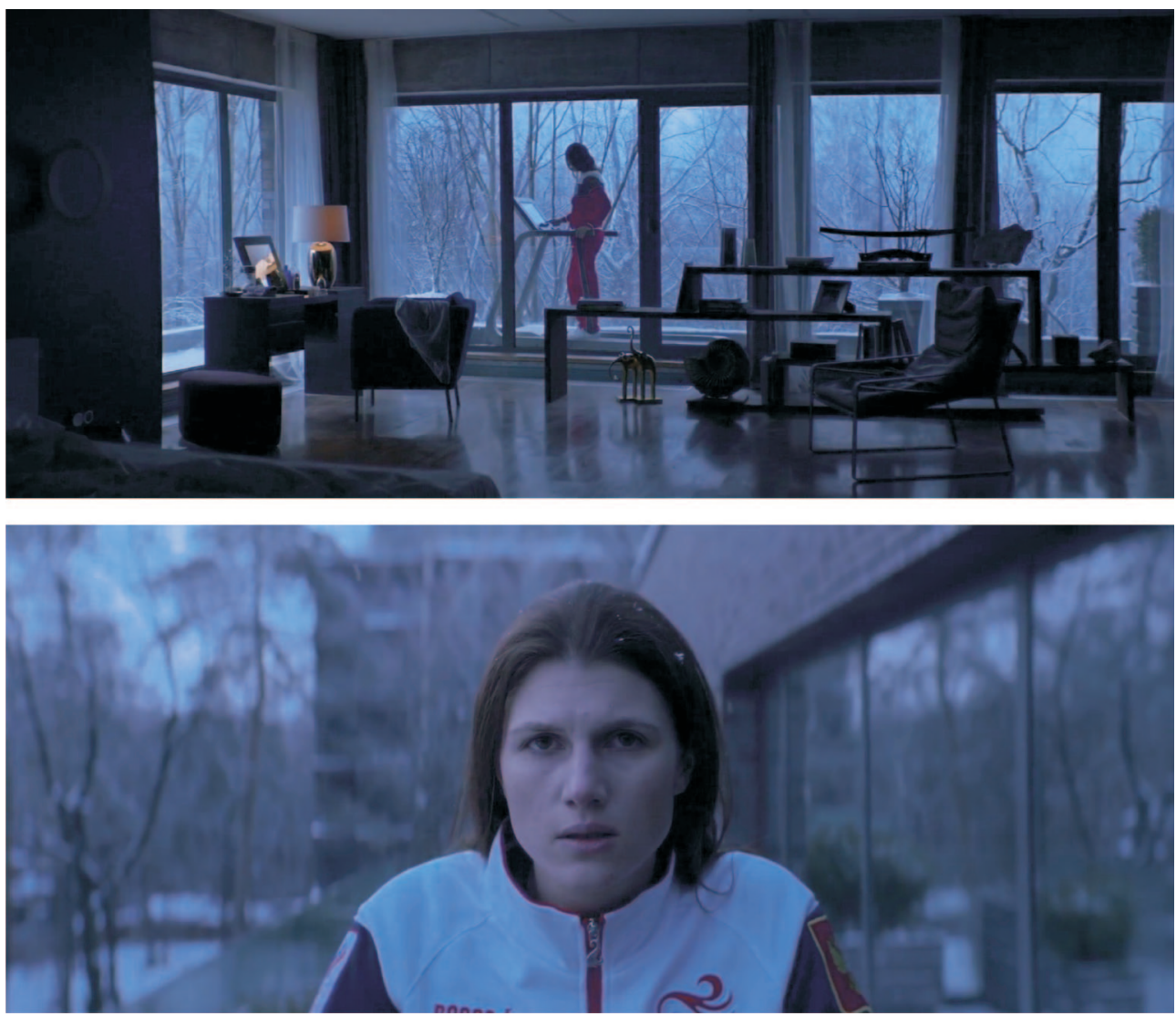
Figure 3. Anita's look on the digitized photograph framed by the computer screen. The Girl with the Dragon Tattoo (2009). Figure 4. The moment when the traumatic material is contained by the framed screen in The Square (2017).
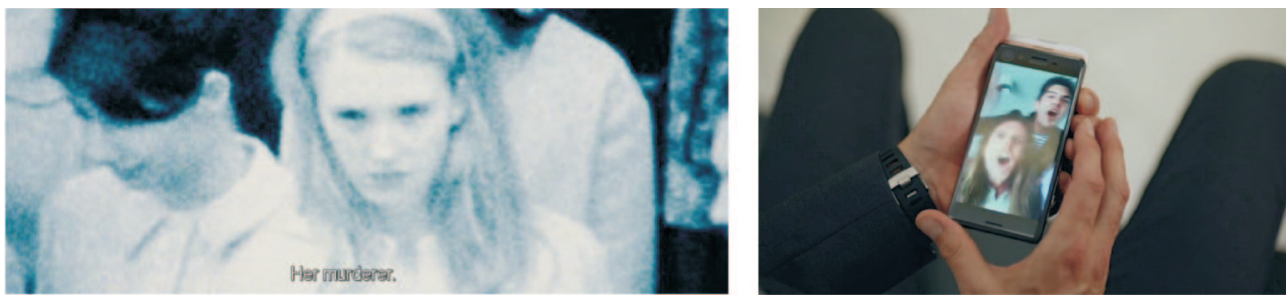

Figure 5. Anna trapped on the black-and-white television screen in the The Commune (2016).

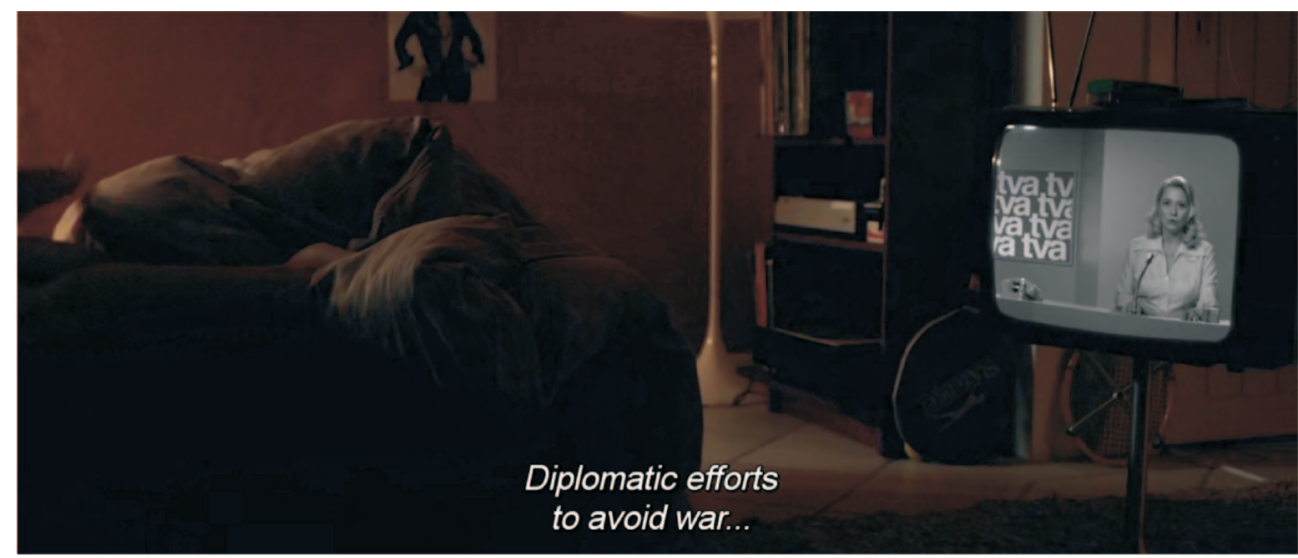

